\title{
A RUA XV DE NOVEMBRO ATRAVÉS DA PERCEPÇÃO DE SEUS PERSONAGENS ${ }^{1}$
}

\author{
Cláudio Pedro Paulo Rosa ${ }^{2}$ \\ Márcia Aparecida Labres de Oliveira ${ }^{3}$
}

\section{Resumo}

Considerar o espaço vivido e suas transformações pela análise em Geografia Cultural constitui-se em elemento fundamental para o conhecimento da sociedade atual. Deste modo este trabalho apresenta alguns aspectos introdutórios referentes à percepção do espaço da Rua XV de Novembro em Curitiba por alguns de seus usuários, que através de suas atividades trazem este espaço certa peculiaridade e transformando-se também em "personagens" ou "marcos visuais" deste espaço.

Palavras-chave: Espaço vivido, percepção, Geografia Cultural, Rua XV de Novembro.

\begin{abstract}
To consider the lived space and its transformations for the analysis in Cultural Geography consists in basic element for the knowledge of the current society. In this way this work presents some referring introductory aspects to the perception of the space of Street Fifteen of November in Curitiba for some of its users, who through its activities also bring this certain space peculiarity and changed ding into "personages" or 'visual landmarks" of this space.

Key-Word: Lived Space, Perception, Cultural Geography, Street Fifteen of November.
\end{abstract}

\section{A Rua XV de Novembro no contexto histórico e cultural de Curitiba}

A cidade de Curitiba é reconhecida por suas inovações urbanísticas, uma destas inovações é a Rua XV de Novembro (Foto 01), localizada no centro da cidade, que através de sua relevância e singularidade tornou-se um dos mais antigos e importantes marcos visuais na

\footnotetext{
${ }^{1}$ Trabalho elaborado na disciplina de Estudos de Percepção em Geografia, ministrado pela Prof ${ }^{\mathrm{a}} \operatorname{Dr}^{\mathrm{a}}$ Salete Kozel,, Departamento de Geografia da Universidade Federal do Paraná.

${ }^{2}$ Aluno de Bacharelado e Licenciatura em Geografia pela Universidade Federal do Paraná. E-mail: claudioprosa@hotmail.com

3 Aluna de Bacharelado e Licenciatura em Geografia pela Universidade Federal do Paraná. E-mail: labres2000@yahoo.com.br
} 
paisagem curitibana. Inicialmente a rua era chamada de Rua da Imperatriz nome que perdurou até a Proclamação da República, quando é renomeada para rua XV de Novembro como forma de homenagem a Proclamação da República.

Por ser um marco central da cidade, sempre foi o palco dos grandes eventos e de concentração comercial da cidade, Assim este espaço sempre esteve incluído no planejamento urbano de Curitiba, tendo sua configuração alterada por várias vezes. No ano de 1913 recebe juntamente com as outras ruas do centro, pavimentação e galerias pluviais, em 1972 transformou-se na primeira grande via pública exclusiva para pedestres do Brasil. Caracterizada por ter um espaço aberto à circulação e ponto de encontro de pessoas, apresenta-se como um espaço de consumo, debate político, manifestações artísticas e culturais (Foto 02), onde os elementos humanos adquirem grande importância.

Estes elementos que se utilizam deste local como meio de subsistência ou como palco para expressão de seu pensamento, destacam-se em relação ao tão "ocupado" e "apressado" povo curitibano, criando assim uma referência local, uma espécie de marco visual humano que remete a memória do lugar. $\mathrm{O}$ fato de pessoas constituírem marcos visuais na paisagem de um local permite a visão dos elementos que dão vida e ritmo a este espaço, visto que eles possibilitam a comunicação e são movidos por sentimentos e necessidades.

\section{A abordagem conceitual em Geografia da Percepção}

A paisagem cultural é composta por elementos físicos, humanos e muitas vezes é o resultado da interação entre eles. Este aspecto é fundamental para entender o dinamismo e a mutação constante que o espaço sofre ao longo do tempo. Os elementos de maior percepção na paisagem são os de ordem física, pois suas formas são mais fáceis de serem apreendidas e possuem maior força no momento da evocação de um lugar. A atenção destinada às formas físicas acaba por tornar o homem um mero ator coadjuvante na percepção da paisagem, embora este seja tão importante quanto um objeto físico, assim

Os elementos móveis de uma cidade e, em especial, as pessoas e suas atividades, são tão importantes quanto às partes físicas estacionárias. Não somos meros observadores desse espetáculo, mas parte dele; compartilhamos o mesmo palco com outros participantes. Na maioria das vezes, nossa percepção da cidade não é abrangente, mas antes parcial, fragmentária, misturada com considerações de outra natureza. Lynch (1997, pág.73).

Deste modo para analisar o homem como atuante e transformador do espaço físico, o método fenomenológico apresenta-se como o mais adequado para este processo, pois considera as reflexões sobre as vivências do homem em seu espaço vivido. Na busca por esta 
compreensão a subjetividade é ampliada na intersubjetividade nesta relação homem/meio e esta subjetividade é encontrada no modo de vida das pessoas: sua religião, sua cultura, hábitos alimentares, símbolos e representações de sua realidade. Analisando estas características o pesquisador consegue capturar a essência de um grupo humano ou individuo e suas reflexões sobre seu meio e sua percepção do espaço.

As correntes do pensar geográfico que abarcam o método fenomenológico são a Geografia da Percepção ou Comportamental e a Geografia Cultural que tem em Yi-FuTuan e Buttimer como principais autores, por elaborarem métodos para a pesquisa geográfica nesta abordagem fenomenológica. Outra corrente importante nos estudos de percepção é a Geografia Humanística, que também utiliza os conceitos da Fenomenologia, buscando a essência das coisas, dos fenômenos e do indivíduo. Não como no Positivismo, onde se observa algo já pronto, mas procurando compreender o fenômeno como ele realmente se materializa. "Uma preocupação central da fenomenologia pura foi a análise e a interpretação da consciência, particularmente a cognição consciente da experiência direta". (BUTTIMER, 1976 apud, CHRISTOFOLETTI, 1982).

Para Anne Buttimer o espaço deve ser considerado pela sua fragmentação, ou seja, é constituído por vários territórios e territorialidades diferentes, como fruto da vontade e memória coletiva dos grupos. Assim os estudos do espaço social investigam a experiência do mundo por meio de sistemas de referência social e redes de interação; a organização espacial é estudada através do contexto da vontade humana. Portanto para o estudo da ação humana, de suas estruturas espaciais e de vida, deve-se ir além de padronizações pré-estabelecidas e analisar o particular dentro de um contexto global, pois só assim será possível a compreensão das diferentes formas de organização espacial. Este é o enfoque da Geografia da Percepção, que propõe uma nova relação com o mundo e uma nova dimensão do homem e define que toda ação humana está profundamente ligada a contextos sociais, físicos, econômicos e que a análise deve ser integral e não parcial.

Para desenvolver este trabalho foi utilizado o sentido de lugar como espaço vivido e espaço social dentro do enfoque fenomenológico proposto por Anne Buttimer, onde o conceito de espaço vivido se apresenta com faces do pré-consciente, pela experiência diária do lugar. Já o espaço social é inerente ao homem atual, por sua mobilidade e suas relações de interação sejam sociais e/ou comerciais, contidas em um determinado espaço. Deste modo este estudo procura inverter a ordem das percepções, buscando uma visão de dentro pra fora, ou seja, a percepção que os marcos visuais (personagens) obtém do local. Acredita-se que esta visão é de grande utilidade nos estudos de Geografia da Percepção, pois a partir dele é 
possível verificar se as lendas, os mitos e a importância dos lugares são as mesmas para as pessoas que fazem deste o seu espaço vivido.

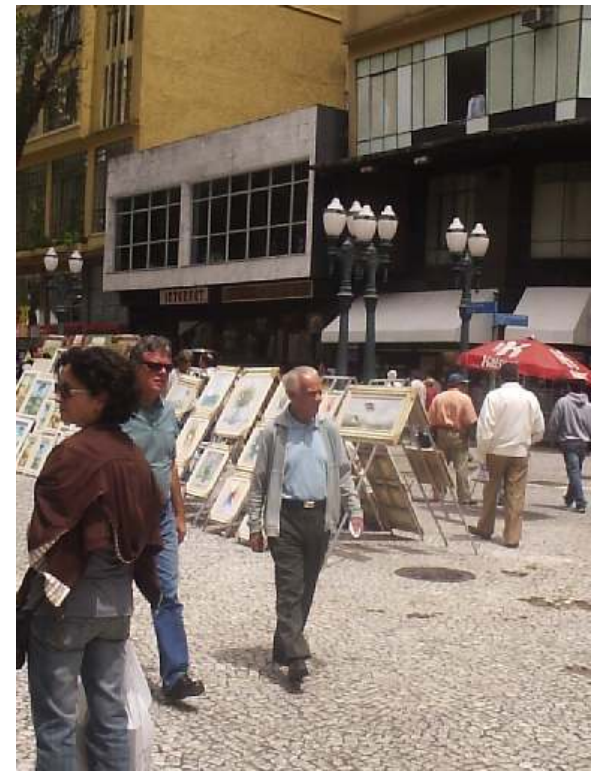

Foto 01: Calçadão da Rua XV

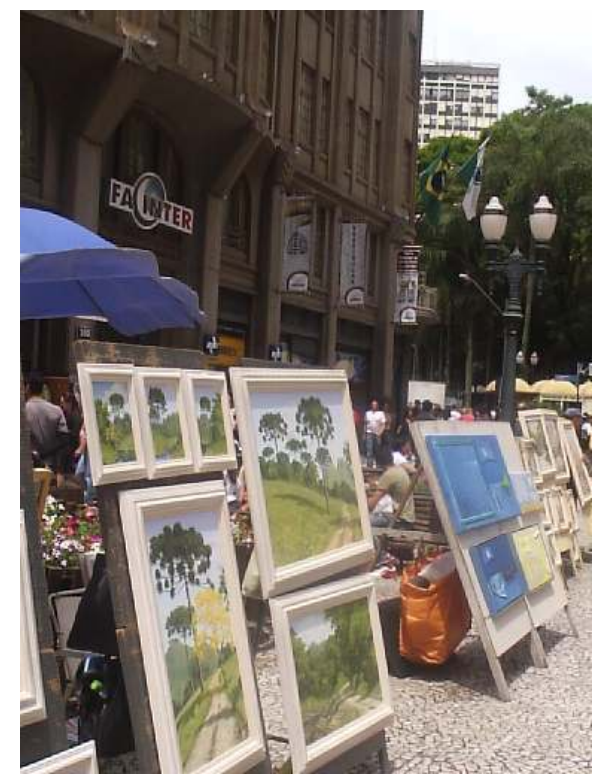

Foto 02: Feira de Artesanato aos sábados

\section{A Rua XV por seus personagens}

Para caracterizar a identificação dos personagens com este espaço singular de Curitiba, escolheram-se cinco "personagens" a partir das atividades por eles exercidas que de alguma maneira trazem para o espaço da Rua XV certa peculiaridade: Artista Plástico/Escultor, O Sombra/Palhaço Chameguinho, O Poeta do Grupo Epopéia, O Plá, músico e A Borboleta 13, Vendedora Autônoma. O trajeto percorrido parte da Praça Osório no calçadão até a esquina da Rua XV de Novembro com a Rua Monsenhor Celso (Figura 01). 
Consideraram-se três aspectos para análise e a elaboração das questões: O primeiro é a percepção que os personagens da Rua XV de Novembro têm das pessoas que freqüentam aquele local. O segundo está ligado a um processo introspectivo, onde estes elementos terão de identificar a sua presença no contexto deste espaço e se consideram que são uma figura diferencial ou não dele, e o terceiro consiste na detecção da relação que os personagens tem com determinados lugares da rua, pois esta possui uma longa extensão, embora a maioria concentre-se próximo a Praça Osório, alguns extrapolam este limite. Os resultados foram obtidos através de trabalhos de campo e entrevistas com os escolhidos, questionário é composto de cinco perguntas abertas, procurando obter respostas subjetivas, onde fosse possível captar a percepção do individuo em relação ao lugar através da fala:

1. Por que você escolheu a Rua XV de Novembro como espaço para demonstrar as sua arte, seu trabalho ou expressar o seu pensamento?

2. Você se considera uma figura diferencial neste espaço? Justifique.

3. Qual é a percepção que você tem do público que freqüenta este local?

4. Como você acha que é a percepção deste público em relação à você?

5. A pesquisa foca a sua atenção nos aspectos humanos e culturais da paisagem, você poderia identificar uma forma física (edifício ou monumento) que remeta a Rua XV de Novembro?

Os trabalhos de campo foram realizados em uma quarta-feira à tarde e num sábado pela manhã, dia de maior movimentação no local, o que permitiu o registro das entrevistas. As respostas foram gravadas e transcritas na íntegra, o que trouxe diferentes e interessantes observações do espaço pelos entrevistados. Quando questionados pelo motivo da escolha da Rua XV como espaço para demonstração de sua arte, seu trabalho e expressar seus sentimentos, os entrevistados em sua maioria confirmaram sua escolha porque a rua é aonde se concentra o maior fluxo de pessoas, que por conseqüência têm um contato maior com o trabalho ou a arte destes personagens, única diferença apontada pelo escultor (Foto 03), é que os transeuntes diários não são consumidores do seu trabalho, mas os turistas que freqüentam a rua ou se hospedam nos hotéis que ali se localizam é que compram suas esculturas.

Aqui em Curitiba só passa pessoas pobre de Curitiba, o rico não passa na $\mathrm{XV}$ ele tem medo, ele só anda em shopping, o bacana não anda na XV nem os filhos dele, a maior parte não conhece nem a XV, o nascido aqui, o bacana... Agora acontece... Vem pessoas de fora aqui, para conhecer a boca maldita aqui, do mundo inteiro, então as pessoas que me compram aqui, quando compra brasileiro é para mandar de presente para o exterior, senão é só os gringo que vem de fora... Aqui é um local bom para vender o meu trabalho, não quero sair daqui não! Se eu for lá para aquela esquina vai diferenciar!! As pessoas que vem neste hotel,, eu vendo para estas pessoas 
deste hotel. Para as pessoas que transitam aqui eu não vendo. Ele vem conhecer a boca maldita, o HSBC que é muito falado, tira umas foto aqui, tira uma foto do bondinho e blup pra dentro do hotel!! Se eu fosse depender do povo curitibano aqui... Ofereço pro brasileiro, pro carioca passa aqui comprar, o gaúcho, o povo de Santa Catarina, mas o povo daqui dificil comprar só mesmo para dar de presente...prá ele mesmo não compra ele vai comprar um liquidificador na casa dele que é o preço de uma peça minha. Ela dá meus parabéns, muito bonito, indica lugar para vender. ..aqui passa a média decaída! Meu trabalho é muito diferencial, para aquele que mora em quatro peças não compra. (P., Escultor)

Já para o "Sombra" (Foto 04), a Rua XV é o palco de suas apresentações há 22 anos.

O artista admite que hoje não viva só dos shows na rua, mas que seu reconhecimento é graças ao trabalho na Rua XV:

É minha trajetória, que esta no meu DVD, desde que eu era ex-menino de rua, saindo de Curitiba para São Paulo, aprendendo a roubar relógios. O primeiro relógio que eu roubei foi do Padre Júlio Lancelotti, e acabei indo para um colégio interno, acabei fazendo um curso de teatro, voltei para Curitiba, me maquiei e comecei fazer meu show, isso há 22 anos atrás e continuo até hoje... Na época escolhi a rua XV por ter uma maior circulação de pessoas, hoje faço show em qualquer lugar, hoje sou muito mais conhecido graças ao meu trabalho aqui na XV. Recebi prêmios, prêmios que até hoje não conhecia, recebi o"Top of Mind", que é para marcas registra das e eu acabei recebendo, quando perguntaram qual é a empresa ou nome que lembra a rua XV o público falou: o sombra!! (C. R. T., artista de rua).

Para o Poeta (Foto 05), do Grupo Epopéia, o motivo mais importante é o fluxo de pessoas de diferentes classes, que vêm para o centro da cidade e torna obrigatório o trânsito pela Rua XV, seja para realizar atividades comerciais, financeiras ou como parte de seu trajeto para o trabalho.

Porque é o corredor diário de pessoas, o ponto de mais fluxo de pessoas é a rua $\mathrm{XV}$, apesar de ter algumas praças movimentadas tudo, por onde as pessoas praticamente, obrigatoriamente passam é a rua XV, se vem para o centro por mais que a pessoa não vá fazer alguma coisa nela passa por ela, é um eixo de transição, as principais lojas da cidade estão na rua $\mathrm{XV}$,principais restaurantes, hotéis, os bancos... Então as pessoas precisam passar na rua $\mathrm{XV}$, é o corredor de fluxos mais intenso,não adianta eu ficar na praça lá também eu pego só um tipo de público... É onde tem a maior variedade de público,pego as pessoas das mais variadas classes, desde uma pessoa pobrezinha que mora na favela até uma pessoa que mora numa cobertura no Batel,que tá passeando olhando o céu. Por isso na verdade. (C.F, Poeta).

A Rua Quinze é um palco aberto para expressão livre, é o pensa o "Plá” (Foto 06), compositor e músico que utiliza o espaço para divulgar seus CDs e suas idéias filosóficas desde 1984; ele acredita que ali o contato com o povo é mais intenso. 
Acho que aqui é um palco aberto pra expressão livre, prá comunicação, prás idéias, como eu tenho assim um trabalho de conteúdo filosófico, nada melhor do que tá diretamente em contato com o povo, escolhi aqui gosto de vir aqui, adoro acho super importante, desde 84 comecei a mostrar minhas músicas aqui,,logo que eu conclui a faculdade de música na FAP,daí eu escolhi vim aqui na rua para apresentar minhas criatividade... Minhas músicas, minha arte ... De lá prá cá sempre tenho freqüentado aqui. (A.A., Músico)

No caso da "Borboleta 13" (Foto 07), a necessidade foi a motivação que a fez começar seu trabalho na Rua XV, no começo vendendo doces, mas com a proibição da fiscalização, passou a comercializar bilhetes de loteria.

Bom, eu foi por motivo de uma necessidade que eu comecei a trabalhar aqui na rua $\mathrm{XV}$, eu comecei vendendo doce, passou né, aquela fase de doce porque os físcal não deixa, daí eu comecei a vender loteria e a loteria então começou a dar certo. Foi por necessidade, por que naquela época eu tinha as criança pequena, isso já faz 38 anos. (T., Vendedora Autônoma)

Quanto ao se reconhecerem como uma figura diferencial deste espaço, apenas o escultor, o poeta e a borboleta 13 se reconheceram como uma figura diferencial, reconhecida em virtude do trabalho desenvolvido por eles, sendo que o poeta diz ser um referencial, inclusive de localização, deste espaço. Os outros entrevistados não se identificam com esta idéia, se consideram pessoas normais, como as outras que freqüentam a rua, que divulgam seu trabalho.

Eu me considero uma figura diferencial na Rua XV, pois sou o único a exercer esta atividade e a necessidade de um trabalho na minha idade... 40 anos... fez que eu trabalhasse com algo que fazia desde a infância... antes eu trabalhava como latoeiro, mas agora sou artesão há 11 anos. (P. Escultor)

Não, eu acho que eu sou igual à qualquer pessoa na rua $\mathrm{XV}$, há uma pequena diferença é que eu faço minha apresentação, faço meu show me maquilo e faço minha apresentação, mas perante a sociedade sou igual à todos. (C. R. T., Artista de Rua)

Pois é , não sei se seria esta a palavra: uma figura diferencial, acho que na verdade acaba se tornando uma figura carimbada,tudo bem pode ser uma figura diferencial porque afinal de contas eu sou uma pessoa que aborda outras pessoas só que para vender seu negócio de poesia, então tem muitas pessoas que vem e que olham você lá de longe e já falam: ó lá o cara da poesia! Outro até aconteceu uma coisa engraçada, até a gente deu risada,tava eu e outro rapaz trabalhando na feira do largo, não tem nada a ver com a $\mathrm{XV}$,mas só pra ilustrar isso aí,uma pessoa passou falando no celular,até então tudo bem, normal,daí ela falou: ah, eu tô aqui, provavelmente a outra pessoa falava: aqui aonde?daí ela respondeu: ahh eu tô aqui aonde fica o cara da poesia! Ou seja fica como uma referência...do lugar onde você está, no caso o cavalo na feira, é o nosso ponto de abordagem, em vez de ela falar do cavalo, falou os cara da poesia. (C.,Poeta) 
Não, não tem muito diferencial eu sou uma pessoa natural,uma pessoa que tem um trabalho de conteúdo filosófico, que apresenta do modo que eu vivo naturalmente, prá mim não tem mistério nenhum(quer levar um cdzinho é dez reais! É um trabalho independente, tá muito bom!! Já tem 33 cds) aí eu deixo essas faixas prá galera escrever e tal, depois eu faço roupa com esses pano" é uma coisa assim de transformação é uma metamorfose!!! Uma idéia assim de vida de caminhada, onde eu vou criando as músicas, vou elaborando meu material,e contactuando Com as pessoas, contribuindo de um modo ou de outro prá que elas sejam mais humana, mais gente né?não fiquem tão bitoladas e fixas neste sistema, que muitas vezes esmaga a personalidade da pessoa, a criatividade da pessoa,então eu procuro sempre dá o alerta, para pessoa descobrir qual o forte dela, desenvolver o potencial dela, ser ela mesma não se vender,não se corromper, não se corroer, dentro de uma estrutura que praticamente condenada e falida e a maioria vai no embalo,nessa do mercado de trabalho, competição,etc e aí que é o grande mal!!! Eu procuro alertar para estes pontos... Não sou diferente de ninguém, faço parte da humanidade. (A. A., Músico)

Eu fico feliz por as pessoa valorizar meu trabalho, sabe, mas eu sou aquela pessoa simples, humilde, que as pessoas escolheram para personagem de Curitiba, eu sou feliz por isso. (T., Vendedora Autonôma)

O público por eles percebido caracteriza-se por serem diversos: turistas, trabalhadores, estudantes, freqüentadores antigos, fãs das apresentações do "Sombra", pobre ou rico. Apenas o Escultor que menciona que as pessoas que compram sua arte são pessoas de fora da cidade, de outras regiões do Brasil e do exterior. Quando o curitibano compra sua escultura é para presentear alguém e geralmente são os que possuem maior pode aquisitivo, já o Poeta aponta a diferença de público entre os dias da semana e o sábado, para ele neste dia as pessoas estão tranqüilas e sem pressa, assim tem um tempo maior para ouvir suas poesias. Mas durante a semana a desculpa da pressa é a mais ouvida.

... o consumidor é só os de fora, pessoas que moram no Brasil inteiro menos o de Curitiba, os de Curitiba são pobres mais um pobre educado, um pobre bacana, eles não são aqueles esculachados entendeu? Aqui pro meu trabalho é muito parabéns, muito que legal e olha você não tem um cartãozinho... O bacana chega aqui e diz quero esse, não tem choro!!! O público de curitiba é mais um admirador, para prá ver o teu trabalho. (P., Escultor)

É um público bastante alvo, tem pessoas que vem aqui todo sábado, ele vem aqui para assistir o show, ai o pessoal que vem de fora, vem os turista hoje o pessoal que frequenta a rua são diversas pessoas, quem tem dinheiro, quem não tem dinheiro, rico, pobre, preto,negro,branco, o polaco, alemão, todas as pessoas que frequentam a rua $\mathrm{XV}$, são ser humanos maravilhoso ,eles adoram o show. (C. R. T., Artista de Rua)

Existe uma diferença das pessoas que vem aqui no sábado, porque no sábado, durante a semana a gente fica próximo a Renner, Galeria Minerva, é pelo que te falei, durante a semana tem a galeria, tem o acesso às lojas, tem a 
Renner,Riachuelo, boticário, a confeitaria das famílias que é bem tradicional, sem dúvida existe uma diferença entre o sábado e os outros dias, porque no sábado existe esta feira,que a gente tá aqui agora, esta exposição das artes, então de qualquer forma a gente tá inserido neste meio, fazemos parte deste meio, então nada melhor do que ficar aqui no meio das artes, e as pessoas no sábado estão mais "despreocupadas", porque a maioria não trabalha no sábado então vem pra passear,vem prá ver as obras de arte, vem prá ver os escultores aqui,os pintores, os artesãos,então vem com um ar mais tranqüilo, não vem com aquela carga do trabalho, da faculdade, da escola, do horário, tô com pressa tô atrasado, primeiro você escuta: tô com pressa, tô com pressa, tô com pressa, é a resposta que a gente mais recebe....as vezes nem sabem por que tão com pressa, mas isso é um hábito curitibano. (C.,Poeta)

O público é ótimo, como eu já falei antes, aqui passa todo tipo de pessoa né, é a população é o povo, não é um público selecionado, é uma coisa aberta, por isso que é bacana! (A. A., Músico)

Olha, eu não tenho pra falar mal eu não tenho nada, mas eu sei que o público muito maravilhoso, a gente tem que saber como tratar o público para ser bem sucedida que nem eu sou com as pessoas né, agora eu tô poco aqui na rua agora, mas aonde eu tô eles vão procurar eu perguntar dos meus bilhetes, fazem óculos ,eu tô numa ótica,né fazendo meus "biquinho", então eu sou muito procurada,agradeço muito a este público maravilhoso! (T., Vendedora Autonôma)

O conteúdo das respostas dos personagens em relação a aceitação de seu trabalho ou arte pelo público que transita na rua XV de Novembro é relativa, se encaixando perfeitamente com a frase do Poeta: "A linha que divide o sublime do patético é tênue". Isto mostra que o carisma destes artistas e trabalhadores que atuam de uma forma diferenciada na Rua XV é um tanto quanto relativo, talvez pelo fato deste local ser freqüentado por um grande número de pessoas com os mais variados tipos de opinião e senso de humor.

Eles gosta muito, é muito parabéns, que Deus ajude, que Deus abençoe, e blábláblá, eles já me conhecem bem, eu não posso falar que sou um referencial... De repente numa dessa eles falam olha só o cara da sucata em frente ao $\mathrm{HSBC}$, aí pode ser, por que aqui ó, aqui geralmente a turma tá filmando, esses tempos me peguei na televisão também, passou na hora do almoço, e de noite também, eu tava aqui, um frio "disgranhento", volta e meia eles vem fazer reportagens e a gente aparece. (P., Escultor)

Existe o seguinte: nem deus conseguiu agradar a todos, tá, não é eu um simples palhaço, um simples artista de rua que vai agradar a todos, tem gente que gosta de mim, tem gente que gosta demais, tem gente que gosta menos, tem gente que me odeia tem gente que me ama, então é normal, mas eu aprendi uma coisa, o povo curitibano é um povo que nunca tá contente com nada, se chove o povo reclama, se esquenta o povo reclama, então quer dizer, eu como curitibano, eu tenho que saber a meta da minha cidade, simplesmente se vai ser sempre, pode vir a melhor coisa do mundo, você por exemplo pode fazer a melhor coisa prá agradar as pessoas, você vai ser criticado por alguém, ou você vai ser chamado de burro ou idiota, ou vai ser chamado de outras 
coisas,é normal... A resposta certa seria, o povo não se agrada com nada! (C. R. T., Artista de Rua)

Difícil dizer né, porque... Como é que eu vou julgar o que o outro pensa, mas são das mais variadas, por exemplo, agora faz cinco minutos, agora, passou uma moça, devia ter uns quarenta e poucos anos, junto com uma senhora, eu perguntei: gosta de poesia? Ela respondeu: não da tua!... Não sei, não a conheço, nunca a vi ,talvez tenha lido minha poesia e não gostou,... Tem gente que não gosta mesmo, é uma questão de gosto, mas tem gente que ama, encontrei dois rapazes que disseram, puxa mais é o onze ainda, não acredito! É isso! Tem os que amam e tem os que odeiam!" A linha que divide o sublime do patético é tênue! (C., Poeta)

Então este povo, público não entende de cara o que eu tento passa com as minhas músicas, depende o conhecimento de uma coisa a mais que transcende esta coisa comum do ser humano,de todo dia, daquela coisa de feijão com arroz, então eu procuro ter uma linguagem mais um pouco de filosófico, onde mostra algo que as vezes até para muitas pessoas elas sentem um choque, elas estão acostumadas com aquela coisa água com açúcar,e aí quando vem falar comigo, ouvir minha música,que tem um outro conteúdo uma outra veia,algo mais voltado a uma saída de tudo essa aglomerado esse turbilhão, esse consumismo, muitos não aceitam bem logo de começo, mas uma boa parte das pessoas já compreende nitidamente o que eu falo, o que eu procuro mostrar, porque eles também tão caminhando, tão evoluindo,tão crescendo e tão vendo como é que tá o mundo, como é que tá a realidade, então estas pessoas logo se aproxima e acabam levando o cd,acabam curtindo, voltando, conversando,fazendo amizade e isto que é mais importante. (A. A., Músico)

Eles valoriza muito o meu trabalho, me elogia muito, agora no meu trabalho eu sou reconhecida: olha a mulher da cobra, a borboleta treze... Eu sou muito agradecida por isso. (T., Vendedora Autonôma)

Quanto à identificação do elemento físico da paisagem que os remete a lembrança da Rua XV, uma coincidência aparece, muitos apontam a Boca Maldita como o principal ícone da Rua, em seguida o Bondinho, o Palácio Avenida e somente a "Borboleta 13" considera como marco visual a esquina da rua Monsenhor Celso com o calçadão, seu local de trabalho. É importante ressaltar que a Boca Maldita é um ponto de encontro para debates políticos, culturais, etc, muitos utilizam seu intervalo no trabalho, para tomar um cafezinho e discutir idéias. Mas ela não é um elemento físico da paisagem, apenas pode ser identificada por uma escultura que a simboliza e que foi inaugurada há 11 anos, mas o lugar é conhecido como Boca Maldita há mais tempo.

A XV mudou muito eu preferia que fosso como era antigamente com rua... Agora gostaria que fosse um calçadão sem transito de carro e nas vias que cruzam aqui, uma passarela, o que me lembra a rua XV sempre é a boca maldita! (P., Escultor)

O que me lembra muito aqui é as discussões políticas, a boca maldita, e os fatos que acontecem porque tudo o que vc quer ver de diferente acontece na 
rua $\mathrm{xv}$, você vê cada coisa na $\mathrm{xv}$ que até deus duvida, a boca maldita é a boca maldita mesmo! (C. R. T., Artista de Rua)

Eu sou curitibano, né... Sou nascido e criado aqui e o meu pai era um cara muito especial e sempre me mostrou coisas legais, sempre me levou nos lugares, apesar de ser uma pessoa bem simples, ... E de certa forma tinha muita poesia nisso, ele me levava no passeio público... Ele me trazia na rua XV prá conversar com os amigos, tomar um café... Daí ele pagava um doce na confeitaria das famílias, uma bomba de chocolate, então ele ia contando historias: do bondinho que funcionava, da rua XV que rua não tinha calçada,.... Falar em rua XV me lembra o bondinho, o bonde 77 que circulava. (C., Poeta)

Primeira coisa que aqui é uma coisa aberta, que transitam pessoas de todo o nível, de conhecimento, de cultura, de percepção, é sempre novidade... Eu venho pra rua XV sempre vou conversar com alguém diferente, por você não saber exatamente o que vai acontecer é que se torna um ponto atrativo da rua, ... A Boca Maldita é o ponto mais marcante, é o trecho da rua que tem a Praça Osório, HSBC e o Bondinho. (A. A., Músico)

O meu troféu de rua XV é a esquina da Monsenhor Celso com o Banestado, aqui onde eu acabei de criar meus filhos neste canto aqui, então aqui prá mim é minha casa, uma parte da minha casa...onde consegui formar meus filhos, foi com o trabalho desta esquina! (T., Vendedora Autônoma)

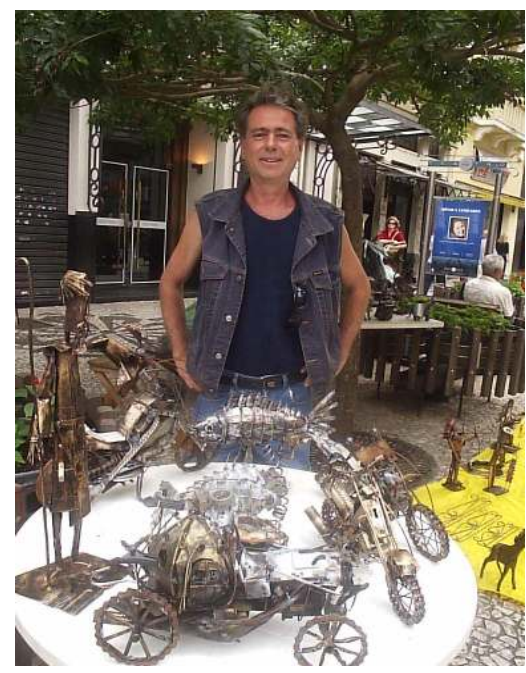

Figura 03: "O Escultor"

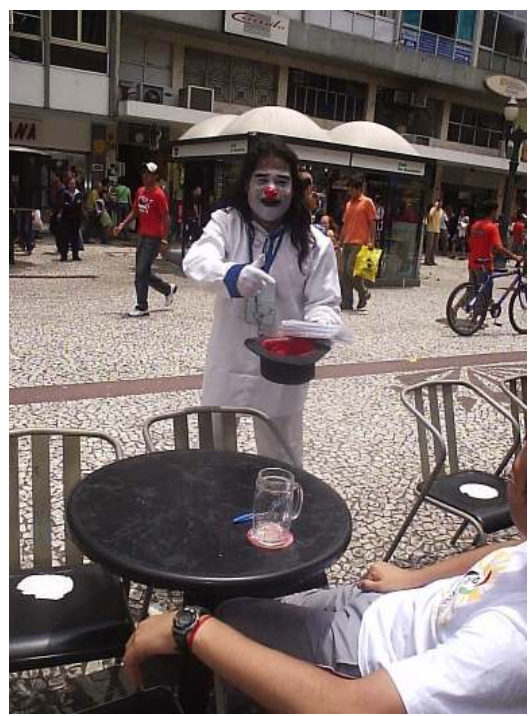

Figura 04: "O Sombra" 


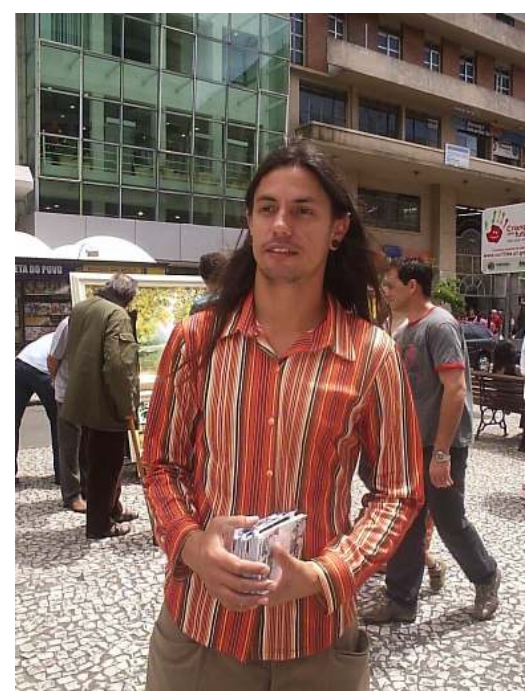

Foto 05: "O Poeta"

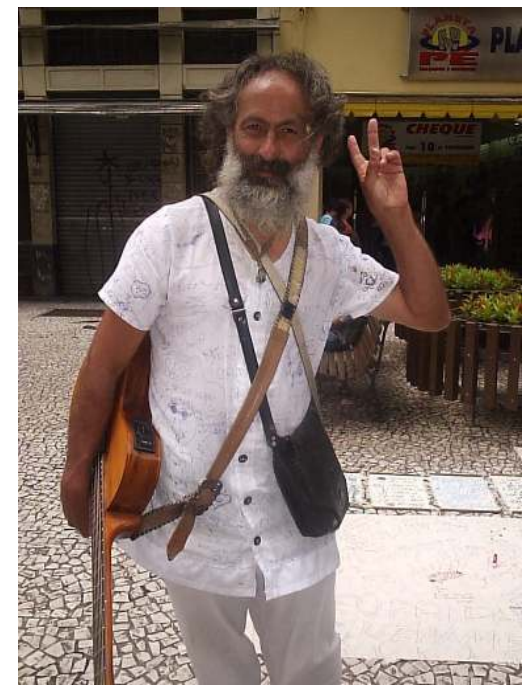

Foto 06: "O Plá"

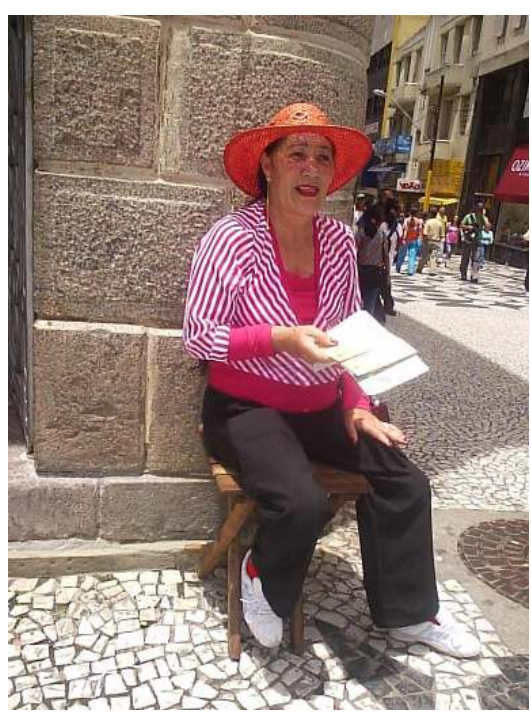

Foto 07: "A Borboleta 13"

\section{Algumas Considerações}

O conceito de espaço vivido evidencia as relações dos homens com os lugares, que deve ser analisado como uma dimensão afetiva e imaginária do homem, integrando o espaço representado que conseqüentemente é o espaço da vida. Já o espaço social e cultural é essencialmente subjetivo, derivado do contato com outras pessoas e que compreende os seres humanos com toda a ação, interesses, trabalhos e atividades.

A visão da Rua XV através das pessoas que divulgam seu trabalho seja de cunho artístico ou não, se dá de forma particular, mas todos a consideram como um local de trabalho, mas também como um lugar das memórias e histórias. Quanto ao reconhecimento de seu trabalho, a beleza estética ao que parece é a mais admirada, pois o artista plástico em sua fala, disse que recebe muitos elogios, assim como a personagem Borboleta 13, esta última 
possui um destaque maior pelo fato de vender seus bilhetes de loteria por 38 anos no mesmo local, acompanhando assim as principais mudanças que a rua sofreu ao longo tempo.

Os artistas que trabalham com um conteúdo que exige uma maior interpretação, como o "Sombra", o Poeta e o músico e filósofo Plá, sofrem a dualidade do ódio e adoração, pois sua obra exige do apreciador a destinação de um maior período de tempo para a interpretação e análise de suas palavras, versos ou ações, fato este, que é percebido em suas falas, considerando que seus trabalhos merecem uns minutos a mais de atenção, pois buscam transmitir algo mais reflexivo, que transcende a rotina diária.

Uma análise equivocada das respostas daria créditos a Boca Maldita como o marco da Rua XV, na concepção dos seus personagens, mas o sentido de mundo vivido de Anne Buttimer esta muito explicito nas falas:

(...) o sentido de mundo vivido emerge como facetas préconscienciosamente dadas da experiência de lugar. Retorna-se à noção de gênero de vida e aos padrões rotineiros aceitos de comportamento e interação”.(BUTTIMER, 1976 apud, CHRISTOFOLETTI, 1982, pág. 83).

Assim experiência diária, assim como a vivida aparece nas falas. Relações de nostalgia, de gratidão ao local de trabalho diário, de socialização aparecem para evocar os lugares da Rua XV. No caso do marco mais citado ser a Boca Maldita é porque existe uma relação de localização, pois a maioria dos entrevistados exerce suas atividades na região. Mas falas como da Borboleta 13, do Poeta e do escultor refletem que a importância desta rua é a do lugar e do mundo vivido. A Borboleta 13 exaltando a esquinas da Rua XV como o seu "troféu" e demonstrando gratidão por aquele espaço, pelo fato de ser o lugar de onde retirou o seu sustento e conseguiu dar uma vida digna aos seus filhos e também as relações de nostalgia do Poeta, ao relembrar os momentos com seu pai citando locais que o tempo e o funcionalismo do espaço apagaram e o Escultor dizendo que preferia a rua em tempos passados.

Respostas como estas demonstram que a Rua XV de Novembro, um dos mais importantes espaços de circulação pública de Curitiba, constitui o seu mundo vivido, não há marcos para estes cidadãos, mesmo porque a Boca Maldita (Figura 08) antes de ter um monumento erigido é um local de debate público. O que existem são lugares que concedem a oportunidade para as pessoas de se socializarem, sobreviverem e expressarem os seus pensamentos, sentimentos e dom artístico. 


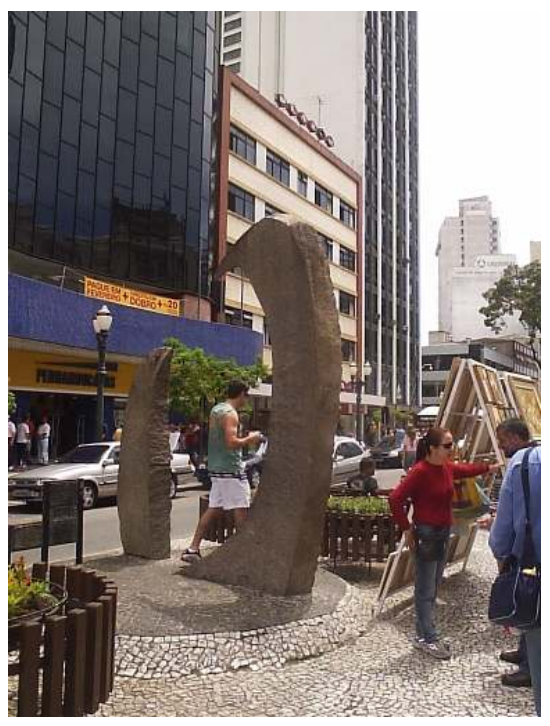

Figura 09: Monumento da Boca Maldita

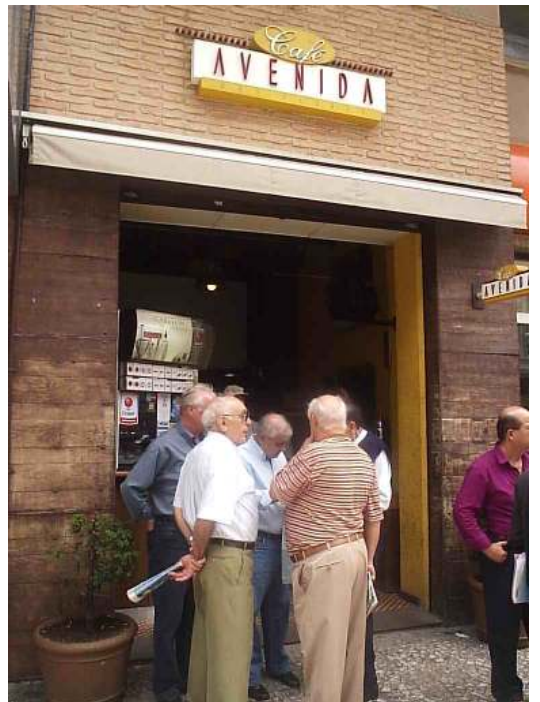

Figura 10: Café da Boca.

\section{Anexos}

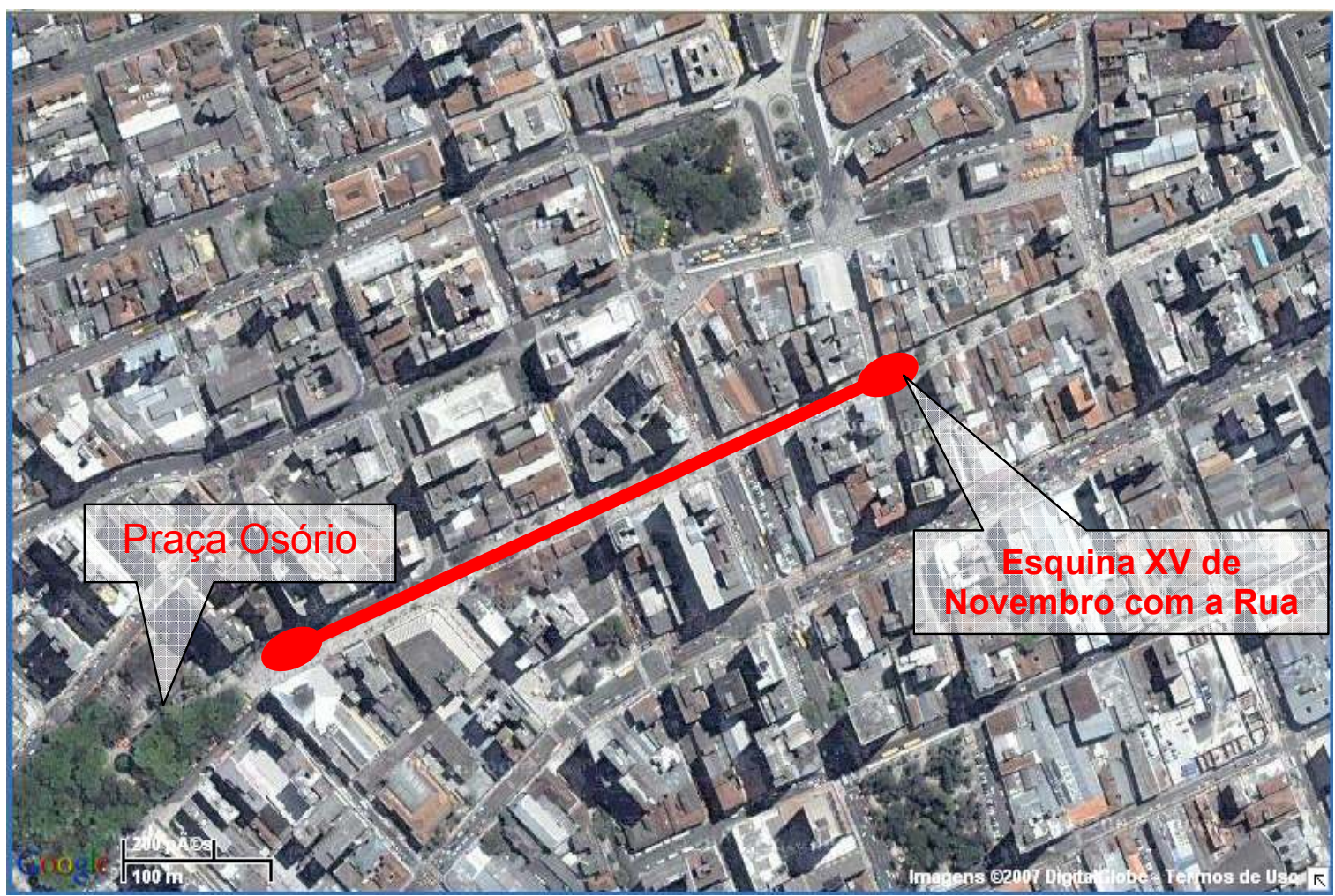

Figura 01 - Imagem de Satélite com trajeto percorrido para entrevistas na Rua XV de Novembro.

\section{Referências}


BUTTIMER, Anne. Aprendendo o Dinamismo do Mundo Vivido. In: CHRISTOFOLETTI, Antônio (org). Perspectivas da Geografia. São Paulo, Difel, 1982.

Concurso Nacional de Literatura. Crônicas Paranaenses: Os vencedores - Curitiba, Secretaria de Estado da Cultura, 1999.

LYNCH, Kevin. A Imagem da Cidade.Tradução: Maria Cristina Tavares Afonso. Edições 70. São Paulo, 2000, número de páginas 208. 